«Про затвердження Положення про організацію навчального процесу у вищих навчальних закладах» № 161 від 02.06.93 [Електронний ресурс]. - Режим доступу : http://zakon2.rada.gov.ua/ laws/show/z0173-93. - Загол. 3 екрана. - Мова укр. 3. Постанова Кабінету Міністрів України № 1719 від 13.12.2006 «Про перелік напрямів, за якими здійснюється підготовка фахівців у вищих навчальних закладах за освітньо-кваліфікаційним рівнем бакалавра» зі змінами, внесеними згідно 3 Постановами КМ № 1193 (1193-2007-п) від 03.10.2007 № 565 (565-2008-п) від 25.06.2008 № 660 (660-2008-п) від 23.07.2008 № 990 (990-2009-п) від 09.09.2009 № 107 (107-2010-п ) від 03.02.2010 № 264 (264-2010-п) від 02.03.2010 № 365 (365-2010-п) від 26.05.2010 № 267 (267-2011-п) від 17.03.2011 № 576 (576-2011-п) від 01.06.2011 [Електронний ресурс]. - Режим доступу: http://zakonl.rada.gov.ua/laws/show/17192006-П. - Загол. $з$ екрану. - Мова укр. 4. Постанова Кабінету Міністрів України № 65 від 20 січня 1998 р. «Про затвердження Положення про освітньо-кваліфікаційні рівні (ступеневу освіту)» (із змінами, внесеними згідно з Постановами КМ № 677 від 23.04.99 № 1482 від 13.08.99) [Електронний ресурс].- Режим доступу: http://zakon.nau.ua/doc/?uid=1059.58.0. - Загол. з екрану. - Мова укр. 5. Сравнительная характеристика систем образования Украины и США [Текст] / Н. Н. Топчий [и др.] // Проблемы и перспективы развития образования : материалы междунар. заоч. науч. конф. (г. Пермь, апрель 2011 г.). - Пермь : Меркурий, 2011. - Т. 2. - С. 203-205.

УДК 378.147:37.32

Дмитро Костюк

\title{
АНАЛІЗ СФОРМОВАНОСТІ ФАХОВОЇ КОМПЕТЕНТНОСТІ В МАЙБУТНІХ ТЕХНІКІВ-ЕЛЕКТРИКІВ СІЛЬСЬКОГО ГОСПОДАРСТВА
}

Костюк Д. А. Аналіз сформованості фахової компетентності в майбутніх техніків-електриків сільського господарства.

У статті на основі проведеного аналізу психолого-педагогічної літератури визначено рівні сформованості фахової компетентності: початковий, базовий, нормативний, творчий. Обгрунтовано основну характеристику цих рівнів. 3'ясовано стан сформованості фахової компетентності в майбутніх техніків-електриків сільського господарства.

Ключові слова: сформованість фахової компетентності, рівень фахової компетентності, фахівець, сільськогосподарське виробництво, технік-електрик.

Костюк Д. А. Анализ сформированности профессиональной компетентности у будущих техников-электриков сельского хозяйства.

В статье на основе проведенного анализа психолого-педагогической литературы определены уровни сформированности профессиональной компетентности: начальный, базовый, нормативный, творческий. Обоснованно основную характеристику этих уровней. Выяснено состояние сформированности профессиональной компетентности у будущих техников-электриков сельского хозяйства.

Ключевые слова: сформированность профессиональной компетентности, уровень профессиональной компетентности, специалист, сельскохозяйственное производство, техник-электрик.

Kostyuk D. A Analysis of the formation of professional competence of future technicians Electrical agriculture. 
On the basis of the analysis of psychological and educational literature the levels of professional competence: beginner, basic, standard, creative are defined. The basic characteristics of these levels are stated. The condition of formation of professional competence of future technicians, electricians of agriculture was found.

Key words: formation of professional competence level of professional competence, professional, agricultural production, electrical technician.

Сучасне аграрне виробництво 3 його інтенсифікацією вимагає підвищення надійності фахівців у всіх галузях аграрного виробництва, в тому числі й енергетиці. Удосконалення процесу підготовки техніків-електриків сільського господарства неможливо без визначення рівнів сформованості фахової компетентності.

I тому, на сучасному етапі становлення особистості техніка-електрика одним із найважливіших завдань $є$ з'ясування стану сформованості фахової компетентності у майбутніх техніків-електриків сільського господарства.

Дослідженням проблеми підготовки техніків-електриків займалося невелика кількість науковців. Так, В. Манько досліджував теоретичні та методичні основи ступеневого навчання фахівців сільського господарства [4]; Ю. Олійник та I. Солошин - проблемні аспекти професійної підготовки майбутніх фахівців енергетичної галузі [5; 6]; П. Лузан - проблеми професійної підготовки майбутніх фахівців технічного профілю в аграрних навчальних закладах [3].

Аналіз наукових досліджень щодо сформованості фахової компетентності свідчить про недостатнє його вивчення, особливо техніків-електриків сільського господарства, зокрема відсутні праці 3 аналізом рівнів сформованості фахової компетентності майбутніх техніків-електриків сільського господарства.

Meта статmі- полягає у визначенні рівнів сформованості фахової компетентності майбутніх техніків-електриків та з'ясуванні стану їі сформованості в них у вищих навчальних закладах аграрного профілю I-II p. a.

Для обгрунтування теоретичних i методичних основ розвитку фахової компетентності у майбутніх техніків-електриків сільського господарства необхідно 3'ясувати його реальний стан, тобто необхідно визначити сформованість критеріїв фахової компетентності, а саме когнітивного, ціннісно-мотиваційного, праксеологічного, суб'єктного та професійно важливих якостей.

У дослідженні брали участь студенти за напрямом підготовки 5.10010102 «Монтаж, обслуговування та ремонт електротехнічних установок в АПК», а саме студенти аграрних ВНЗ I-II рівнів акредитації. Загальна кількість опитаних складає 251 студент. Результати анкетування студентів оброблялися комп'ютерною програмою SPSS.

Сформованість фахової компетентності у майбутніх техніків-електриків сільського господарства у процесі вивчення спеціальних дисциплін визначали за чотирма рівнями: I рівень - початковий; II рівень - базовий; III рівень - нормативний; IV рівень - творчий. Визначення таких рівні $є$ результатом проведеного аналізу сучасних вимог до майбутніх техніків-електриків сільського господарства, аналізу посадових обов'язків фахівців енергетичної служби другої половини XX ст. [2] i кваліфікаційних характеристик професій енергетичної служби в сучасних умовах в Україні [1] за групами професій енергетичної служби.

Отже, І рівень - початковий. Він характерний для студентів, які мають початкові показники 3 більшості критеріїв сформованості фахової компетентності. У таких студентів відсутні, практично, фахові інтереси, потреби, мотиви, цінності та позитивне ставлення до майбутнього фаху техніка-електрика. Вони часто з таким 
рівнем ціннісно-мотиваційного критерію вибір своєї професії пояснюють такими висловами: «Вступив туди, де, була можливість», «Вибрав цей ВНЗ тому, що він найближче до мого дому», «Навчання за цією спеціальністю коштує недорого» тощо.

Студенти не можуть визначити технічний стан електрообладнання, затрудняються у його діагностиці, часто допускають помилки у процесі самостійного діагностування, 3 великими труднощами здійснюють планування профілактичних $\mathrm{i}$ ремонтних робіт, розрахунок потреби в техніці та часі, необхідні для виконання запланованих робіт.

У них повністю відсутні: інтерес до фаху техніка-електрика; бажання розв'язувати професійні завдання та розуміти загальні принципи виробничих процесів тощо.

Також слабо виражені фахові навички та уміння, а рівень фахового мислення знаходиться на початковому етапі, фаховий досвід- повністю відсутній. Слабо володіють основними логічними операціями.

Професійно важливі якості виявляються на початковій стадії формування, при цьому така якість, як винахідливість, повністю відсутня.

Суб’єктний компонент несформований або сформований дуже слабо, причиною цього є байдуже, а інколи і негативне ставлення до майбутнього фаху.

II рівень - базовий. Студенти цього рівня мають позитивне, але водночас пасивне ставлення до майбутнього фаху та процесу набуття професійної освіти у ВНЗ I-II p.a. За більшістю критеріїв фахової компетентності студенти мають середній і нижче середнього показник.

Фахові інтереси, потреби, мотиви мають нестійкий характер, цінності та ставлення до набуття фаху техніка-електрика, не підкріплені активною позицією. У частково змінених ситуаціях його дії мають виконавчий характер. Інтерес до науководослідної роботи дуже слабий, але вміння розв'язувати фахові завдання сформовані.

Характер засвоєння знань реконструктивний. Загальнотехнічні, професійні та технологічні знання визначаються на рівні вміння розв'язувати прості задачі. Під час використання інструкції вони можуть працювати 3 навчальною i довідковою літературою, приладами, таблицями тощо. Деякі 3 них займаються самоосвітою. Знання засвоюються в межах 50-60 \% від загального обсягу.

Під час визначення стану електрообладнання, проведенні його діагностування, виявляють невпевненість у своїх діях і часто звертається за допомогою, але непогано справляються з плануванням профілактичних і ремонтних робіт, розрахунком потреб у техніці та часі, які необхідні для виконання запланованих робіт.

Частково розвинені професійно-важливі якості, при цьому в деяких студентів спостерігається розвиток скрупульозності в роботі.

У студентів помічається сформованість суб'єктного компонента, але частина 3 них все одно не прагне до сприйняття фаху техніка-електрика як власного майбутнього професійного буття.

III рівень - нормативний, який характерний для майбутніх техніків-електриків, які виявили позитивний інтерес до фаху та до процесу формування фахової компетентності. 3 більшості критеріїв фахової компетентності мають підвищені показники.

Фахові інтереси, потреби, цінності та ставлення носять стійкий характер, а мотивація більш стійка, ніж на базовому рівні, має відносно стійкий інтерес до навчальної діяльності, присутнє бажання шукати нову інформацію, висувати різноманітні ідеї та гіпотези. У деяких студентів помітний інтерес до науководослідної роботи. 
Майбутнім технікам-електрикам спеціального рівня притаманна добра сприйнятливість навчального матеріалу, хороша успішність у навчальній діяльності, яка має самостійний характер, успішна праця з довідковою і навчальною літературою, приладами, таблицями тощо. Вони беруть активну участь у конкурсах, олімпіадах. Знання засвоюються в межах 60-70 \% від загального обсягу.

Рівень сформованості фахових умінь, навичок, практичного мислення, досвіду $є$ достатнім. Добре розвинені професійно-важливі якості, в деяких студентів розвиток скрупульозності в роботі та самозбереження знаходиться на високому рівні розвиненості. Можуть передбачувати можливі недоліки в роботі, мають схильність до саморозвитку та самореалізації.

Суб'єктний критерій визначається досить стійким усвідомленням необхідності опанування майбутньої професії техніка-електрика. Тільки в невеликої кількості студентів виникають вагання, щодо правильності вибору фаху. Їхня думка така: «Упевнений, що ця професія мені допоможе реалізуватися, досягти успіху та матеріального статку».

IV рівень - творчий - це найвищий рівень сформованості фахової компетентності. Всі критерії сформованості фахової компетентності при цьому мають високі показники.

Студенти мають стійкий інтерес до навчальної діяльності та майбутньої фахової діяльності, повністю сформовані фахові знання, високий рівень розвиненості основних компонентів фахової компетентності, здійснюють постійний аналіз та самоаналіз своєї діяльності.

Рівень загальнотехнічних, професійних, аграрних, екологічних, управлінських i технологічних знань знаходиться на високому рівні, що забезпечує здатність здобувати нові знання і має, наскільки це можливо, творчий характер. Знання засвоюються в межах 80-100 \% від загального обсягу.

У них на високому рівні розвинений інтерес до науково-дослідної роботи, розв'язування професійних завдань, усвідомлення загальних принципів виробничих процесів і фахової культури. Мають здатність до інтеграції 3 вітчизняним, зарубіжним, інноваційним досвідом і здатні прогнозувати, передбачувати проблеми й знаходити шляхи їх вирішення, можуть швидко оволодіти сучасними технологіями.

Проявляють готовність раціонально діяти в різних виробничих ситуаціях, уміють оперувати загальнотехнічними, професійними, аграрними та технологічними знаннями в цій діяльності, здатні надавати суттєву допомогу в роботі своєму товаришеві.

Для визначення рівні сформованості фахової компетентності у майбутніх техніків-електриків сільського господарства використовували комплекс діагностичних методик. Розв'язуючи це завдання, використовували вже відомі методики діагностування окремих якостей особистості фахівця, застосовували спостереження за студентами, при цьому створюючи спеціальні ситуації, проводили бесіди 3 студентами та педагогічними працівниками, анкетування, експертне оцінювання тощо.

Яким би із методів визначення не користувалися, вимір фахової компетентності $\epsilon$ до певної міри суб'єктивним і насамперед відбиває позицію дослідника з означеної проблеми. У зв'язку 3 цим, при визначенні показників, які характеризують компетентність фахівця, передбачається вивчення зовнішніх (об'єктивно-предметних) і внутрішніх (суб'єктивно-особистісних) складників його діяльності.

За результатами тестування у студентів були з'ясовані такі рівні сформованості фахової компетентності майбутніх техніків-електриків сільського господарства (табл. 1): 
Результати сформованості фахової компетентності у майбутніх техніків-електриків сільського господарства

\begin{tabular}{|c|c|c|c|c|c|c|c|c|}
\hline \multirow{3}{*}{ 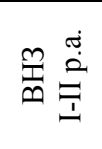 } & \multicolumn{8}{|c|}{ Рівні сформованості } \\
\hline & \multicolumn{2}{|c|}{ початковий } & \multicolumn{2}{|c|}{ базовий } & \multicolumn{2}{|c|}{ нормативний } & \multicolumn{2}{|c|}{ творчий } \\
\hline & $\begin{array}{l}\text { кількість } \\
\text { студентів }\end{array}$ & $\%$ & $\begin{array}{l}\text { кількість } \\
\text { студентів }\end{array}$ & $\%$ & $\begin{array}{l}\text { кількість } \\
\text { студентів }\end{array}$ & $\%$ & $\begin{array}{l}\text { кількість } \\
\text { студентів }\end{array}$ & $\%$ \\
\hline 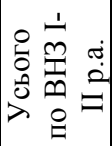 & 127 & 50,6 & 63 & 25,1 & 45 & 17,9 & 16 & 6,4 \\
\hline
\end{tabular}

3 отриманих результатів за п’ятьма критеріями фахової компетентності можна зробити такі висновки:

1) більшість студентів мають початкові показники 3 усіх критеріїв сформованості фахової компетентності; зокрема, в них, практично, відсутні фахові інтереси, потреби, мотиви, цінності та позитивне ставлення до майбутнього фаху техніка-електрика сільського господарства, що складають мотиваційний фундамент для розгортання та конкретного змістовного наповнення усіх іiі критеріїв і насамперед інтегрального критерію - суб'єктного;

2) рівень сформованості фахових знань у переважної більшості студентів знаходиться на рівні впізнання і має, в основному, репродуктивний характер; відповідно, виникає проблемне питання щодо активізації творчого опанування ними фаховими знаннями шляхом застосування активних методів навчання.

3) у більшості студентів відсутній професійний інтерес і позитивне ставлення до фаху техніка-електрика сільського господарства, а спостерігаються лише в невеликої кількості студентів сукупність умінь розв’язувати професійні завдання та розуміння загальних принципів виробничих процесів в агарному секторі;

4) у переважної більшості студентів тільки частково сформовані професійно важливі якості, хоча для їх формування $є$ позитивні передумови, оскільки в окремих студентів сформульована скрупульозність у роботі та почуття самозбереження;

5) у частини студентів помічається сформованість окремих показників суб'єктного критерію, але переважна більшість 3 них все одно не прагне до сприйняття фаху техніка-електрика як власного майбутнього професійного та фахового буття, що безумовно виступає дезінтеграційним моментом їх життєдіяльності на етапі набуття фахової компетентності у процесі вивчення спеціальних дисциплін в аграрних ВНЗ I-II p. а.

Отже, можна зробити такий загальний висновок: рівень сформованості фахової компетентності в більшості студентів характеризується як як початковий та базовий. Лише в невеликої частини студентів діагностовано творчий та нормативний рівень фахової компетентності, в яких також за більшістю критеріїв фахової компетентності спостерігається середній показник.

У подальшому плануємо розробити методику щодо підвищення ступеня сформованості фахової компетентності у майбутніх техніків-електриків сільського господарства й експериментально перевірити іiі.

\section{Література}

1. Довідник кваліфікаційних характеристик професій працівників. - 
Краматорськ: Центр продуктивності, 2005. - Вип. 1: Професії працівників, які $€$ загальними для всіх видів економічної діяльності. - 363 с. 2. Должностные обязанности специалистов колхоза в условиях полного хозрасчета / Сост. Г. А. Баклаженко. - М. : Росагропромиздат, 1989. - 416 с. 3. Лузан П. Г. Теорія професійної підготовки спеціалістів : [текст]/ П. Г. Лузан, П. М. Решетнік, Н. С. Журавська. - К. : Видавничий центр НАУ, 2003. - 130 с. 4. Манько В. М. Теоретичні та методичні основи ступеневого навчання фахівців 3 механізації сільського господарства : [текст] / В. М. Манько, В. В. Іщенко. - К. : Аграрна освіта, 2003. - 431 с. 5. Олійник Ю. С. Методика тестування знань 3 електромагнітних перехідних процесів у майбутніх інженерів-електроенергетиків : автореф. дис. на здобуття наук. ступеня канд. пед. наук : спец. 13.00.02 «Теорія і методика навчання» / Ю. С. Олійник. $-\quad$ Х., 2011. - 20 c. $\quad$ 6. Солошин I. О. Методика формування екологічних знань у майбутніх інженерів-електромеханіків у процесі навчання спеціальних дисциплін : автореф. дис. на здобуття наук. ступеня канд. пед. наук : спец. 13.00.02 «Теорія і методика професійної освіти»/ I. О. Солошин. - Харків, 2006. $-20 \mathrm{c}$.

\section{ПРОБЛЕМИ ФАХОВОЇ ПІДГОТОВКИ СТУДЕНТІВ-ГЕОДЕЗИСТІВ}

Куліковська О. С. Проблеми фахової підготовки студентів-геодезистів.

У статті проаналізовано результати анкетування студентів-геодезистів 1-5 курсів щодо їхнього ставлення до освітнього процесу у Криворізькому національному університеті. Розглянуто сутність і особливості застосування роздавальних анкет, визначено мету опитування, розроблено форму і запитання анкети. Відображено запитання, пов'язані з оцінкою якості навчання, судженням достатності лекційних, лабораторних і семінарських занять, оцінюванням відвідуваності й інтересу до навчання загалом, до проведення навчальних і виробничих практик.

Ключові слова: студенти-геодезисти, анкетування, освітній процес, якість навчання, інтерес до навчання, репрезентативність.

Куликовская О. Е. Проблемы профессиональной подготовки студентовгеодезистов.

В статье проанализированы результаты анкетирования студентов-геодезистов 1-5 курсов их отношения к образовательному процессу в Криворожском национальном университете. Рассмотрены сущность и особенности применения раздаточных анкет, определена цель опроса, разработаны форма и вопросы анкеты. Отражены проблемы, которые связаны с оценкой качества обучения, суждение о достаточности лекционных, лабораторных и семинарских занятий, оценка посещаемости и интереса к обучению, к проведению учебных и производственных практик.

Ключевые слова: студенты-геодезисты, анкетирование, образовательный процесс, качество обучения, интерес к учебе, репрезентативность.

Kulikovska O. Ye. Problems of professional training of students of surveyors.

The article analyzes the results of the survey of students surveyors of 1-5 years of study in relation to the educational process in Krivoy Rog national University. The article considers the nature and peculiarities of distributing questionnaires, defines the purpose of 